\title{
6 ASSESSMENT AND MANAGEMENT OF PAEDIATRIC PRIMARY SURVEY NEGATIVE PATIENTS
}

\section{F Jewkes, M Woollard}

Emerg Med J 2004; 21:595-605. doi: 10.1136/emj.2004.017780

$T$ his paper describes the assessment and findings associated with illnesses that commonly affect children. It aims to be a guide to common presentations and treatment rather than a comprehensive review of all paediatric conditions. A previous article has described the identification and initial management of potentially life threatening problems. Box 1 describes the objectives for this article.

\section{Box 1 Article objectives}

\section{Objectives}

1. To describe the approach to the secondary survey in children and its main features

2. To discuss differential diagnosis for children with common presenting symptoms

3. To describe the differential diagnosis, management, and disposition of children with a range of common conditions

4. To review indicators of the need for hospital referral

5. To describe the care of common problems affecting technologically assisted children

6. To consider the importance of communication in the care of the sick child

\section{SECONDARY SURVEY}

A secondary survey will be required on all children who have not required transfer to hospital after the primary survey (see article 5 in this series). Its aim is to fully assess the child so that decisions about their future management and disposal can be safely made. The SOAPC system (box 2) can be used to undertake this survey but is modified to take account of the particular needs of children (see article 5).

\section{Box 2 SOAPC assessment strategy}

- Subjective assessment

- Objective examination

- Analysis and diagnosis

- Plan (treatment and disposal)

- Communication

See end of article for authors' affiliations

Correspondence to: Mr M Woollard, Department of Academic Emergency Medicine, Education Centre, The James Cook University Hospital, Marton Road, Middlesbrough TS4 3BW, UK Malcolm.woollard@ ukgateway.net

\section{Subjective assessment}

Most parents and carers will be very sensitive to changes in their children's health. Consequently if they express concern about their child's wellbeing they are often right. Ask parents or carers what they think the matter is and, if appropriate, what treatment they might be expecting. They may relate treatments that have helped the child during similar illnesses, and this will help to identify the parent's expectations about what they believe is required.

If necessary, ask parents what constitutes normal behaviour and appearance for their child, and to always involve the patient in the discussion. Even toddlers and younger school age children should be spoken to directly, using language appropriate to their ability to understand. It may be helpful to assess teenagers without parents or guardians present to encourage them to discuss their illness and any concerns they may have openly.

As well as a detailed history of the presenting complaint, details of past illnesses or operations, medications, and allergies should be sought and recorded, as should the family history. Birth history may also be important, particularly in infants and younger children. On occasion a brief developmental history may also shed light on the problem. 


\section{6}

The parents of children with chronic illnesses (such as renal disease) or congenital problems are likely to have considerable expertise about assessment and management of the condition-as indeed may the children themselves. Practitioners should not be dismissive of the information and suggestions made by "expert" parents and children.

\section{Objective examination}

Before approaching a child directly, observe their general behaviour. Are they passive or active? Are they playing normally? Do they pay attention to their surroundings? (fig 1).

As you approach the child, consider their affect. Is this normal for their age group? Have they reacted to your presence (perhaps by hiding behind the furniture)? Consider the child's general condition-do they appear well cared for, or are they grubby and thin?

The content of the physical examination should be similar to that for an adult, although the order in which each system is assessed may be modified depending on the age and behaviour of the child (see article 5 in this series on primary survey positive children). There are some aspects, however, that are particularly important to paediatric examination:

\section{Temperature}

Taking the child's temperature is of limited value in primary care. There are various confounding problems (such as whether or not the child has received an antipyretic and what part of the body is used to assess temperature) and the presence or absence of a fever does not confirm or rule out serious disease. Indeed authorities still debate what the upper limit of normal is. It is, however, recognised that very young babies (for example, less than 6 months old) who have a significant fever (greater than $38.5^{\circ} \mathrm{C}$ ) or who are hypothermic are likely to have serious disease. Young children may sometimes tolerate very high temperatures (in excess of $40^{\circ} \mathrm{C}$ ) with little apparent discomfort or serious pathology. Significant fever can usually be detected, if no thermometer is available, by touching the skin of the child's trunk.

\section{Skin}

The presence of a rash may be significant. Note its morphology, pattern, and distribution and assess its significance in the light of the associated symptoms and signs (fig 2).

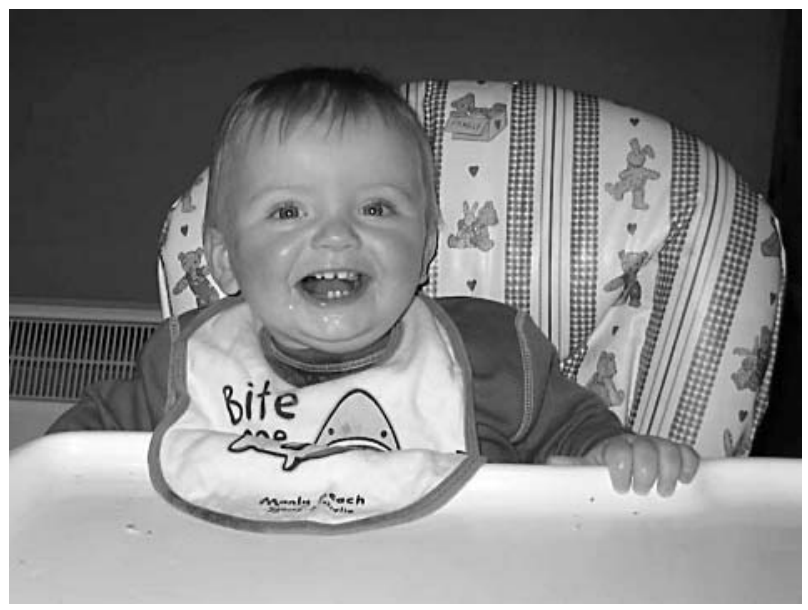

Figure 1 A happy, alert baby (picture courtesy of Fiona Mair).

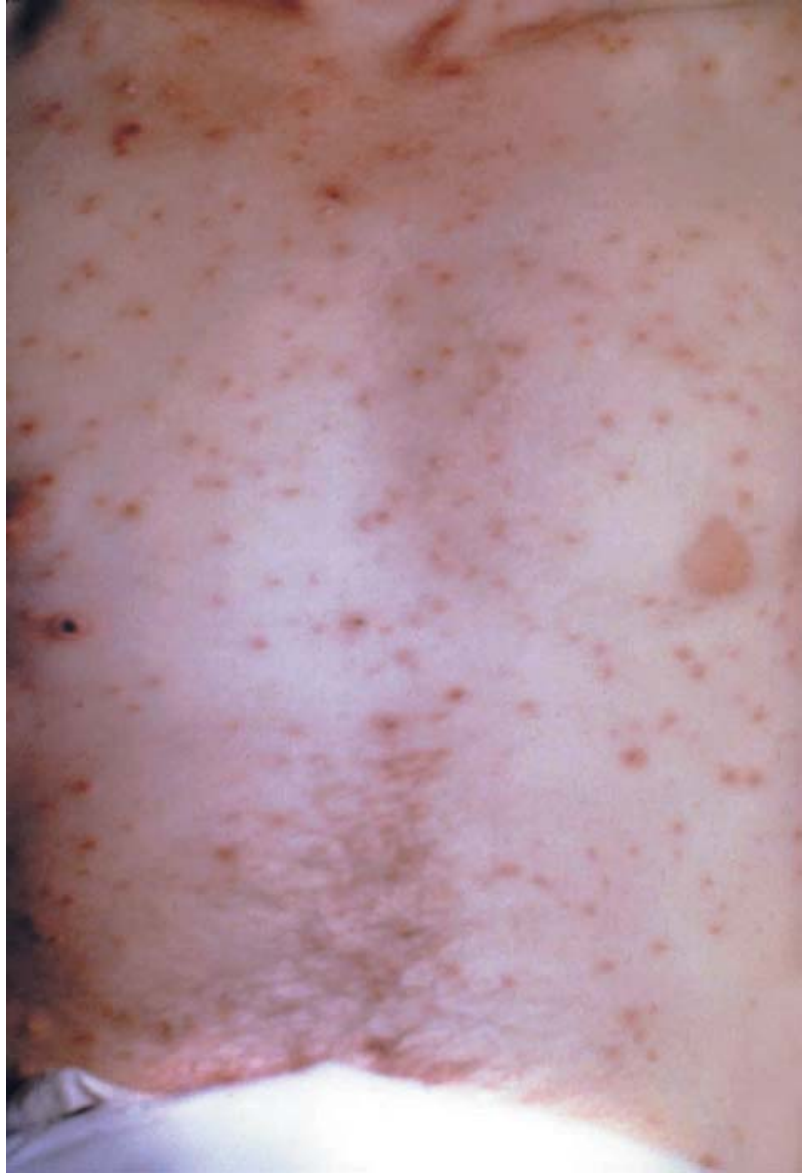

Figure 2 Chicken pox (picture courtesy of the Advanced Life Support Group).

\section{ENT}

The ears should be examined using an auroscope, and the throat for evidence of tonsillitis or other pathology.

\section{Reticuloendothelial system}

Lymphadenopathy may indicate glandular fever, other viral infections, or less common pathology such as leukaemia. Cervical lymphadenopathy is extremely common in upper respiratory tract infections and its presence may lead the child to tell you that his or her neck hurts when it is flexed. This should not be confused with the neck stiffness seen in meningeal irritation. When palpating the abdomen check for organomegaly. Splenomegaly is fairly common in viral illnesses but its presence must be noted and the assessment repeated when the child recovers to ensure that it resolves. The liver may be palpated without difficulty in the young baby and is easily pushed down in conditions where the lungs are hyperinflated such as bronchiolitis. This must be distinguished from actual enlargement suggesting cardiac failure, metabolic disorder, or malignancy.

\section{Blood sugar measurement}

While blood sugar measurement is essential in all children who have a disturbed conscious level, it need not be done routinely in the child who does not appear to be seriously ill, unless there is a particular reason such as a suspicion of diabetes. 
Urine cultures (refer to general practitioner)

These need to be obtained in any child who is unwell and in whom the cause is not clear, particularly in the presence of febrile convulsions. It is important to obtain urine for culture before starting antibiotics for suspected urinary infection. The parent can be instructed to collect the urine before starting antibiotics and store it in the refrigerator until the next day, when the child's GP can send it for culture.

\section{金 Pitfall}

There are almost no indications for a rectal or vaginal examination in children in the primary care setting

\section{含 Tip}

Children who grab your stethoscope and play with it, and who can be made to laugh by wobbling their tummy are not usually seriously ill!

\section{Analysis (differential diagnosis) and treatment and disposal (plan) Common presentations}

The irritable child

A common presentation that can be difficult to sort out is the baby who is reported to cry excessively. If the baby does indeed appear to be irritable and dislike handling they must be assumed to have serious illness and be admitted urgently to hospital. More common is the baby who will not settle or settles only briefly: these children can cause considerable concern to new parents and healthcare professionals alike. The cause may be attributable to a multitude of reasons from significant pathology to parents who are insecure and not coping. Even when the practitioner can confidently determine there is no significant clinical problem (difficult at the best of times) admission to hospital or referral for further support should be considered if parents remain anxious. If there is any doubt at all that the child is genuinely irritable, they should be referred, as the pathology associated with irritability is often serious (for example, meningitis).

\section{越 Tip}

Children who have become suddenly and unusually irritable should be considered to be acutely ill until proved otherwise

\section{Abdominal pain}

Abdominal pain in children can also cause diagnostic conundrums. If the child is seriously ill (primary survey positive) they should be managed with immediate transfer to hospital and appropriate resuscitative measures. If the child is not seriously ill, diagnostically they can be divided into acute and chronic presentations. Intermittent chronic abdominal pain in children is very common but more likely to present as a routine rather than emergency referral. Causes are diverse and beyond the scope of this discussion-some of the commoner causes are urinary infection, constipation, abdominal migraine, and idiopathic (the aptly named "recurrent abdominal pain of childhood"). Acute abdominal pain is common and a systematic approach required. Possible surgical pathology must be excluded and if this is not possible, the child referred for more detailed assessment. Acute appendicitis may be very difficult to diagnose in small children and must be actively considered. Urinary tract infection often presents non-specifically with abdominal pain with or without urinary or systemic symptoms and must also be considered. One of the commonest non-surgical causes is mesenteric adenitis (acute lymphadenopathy in the abdominal lymph nodes) and a concurrent upper respiratory infection is characteristic. Infective gastroenteritis, Henoch Schonlein purpura (HSP), and many other disorders all have their own range of associated features and symptoms. If in doubt, refer for further investigation.

\section{领 Pitfall}

Infants and toddlers normally have a protuberant abdomenthis should not be confused with pathological distension

\section{瑜 Tip}

Unilateral pain is a significant finding, and the further the pain is from the umbilicus the more likely it is to be organic, but remember that small children localise abdominal pain poorly and will tend to point to the umbilicus as the location.

\section{The febrile child}

Reducing the temperature of febrile children does not have any significant benefit in reducing the length or severity of the associated illness. However, simple antipyretics such as paracetamol (known as acetaminophen in the USA) or ibuprofen (which can be used concurrently) can reduce the misery for both child and carer alike.

\section{ENT problems}

ENT problems are common in children. Infants are obligate nasal breathers up to about 6 months of age. Consequently a blocked nose may result in a significant increase in the work of breathing and may produce difficulty feeding. Otitis media, presenting with a red and sometimes bulging or perforated eardrum, is a common finding in a child with earache. Antibiotics have not been shown to change the outcome of the disease in the majority of patients but are still often given. Otitis externa is less common, usually also presents as earache, with or without a discharge.

Foreign bodies may be pushed into the ear by small children or, more commonly, into the nose, and should be sought for in the presence of a snuffly child without symptoms of illness. The throat should be carefully examined in all sick children unless epiglottitis or croup is suspected. Streptococcal infections and glandular fever can cause petechial rashes on the palate, ulcers may indicate a coxsackie virus infection, and Koplik's spots (although very uncommon nowadays) are indicative of measles. Swollen red tonsils, with or without exudates, and accompanied by flulike symptoms suggest tonsillitis, and unilateral enlargement may suggest a peri-tonsillar abscess. 


\section{8}

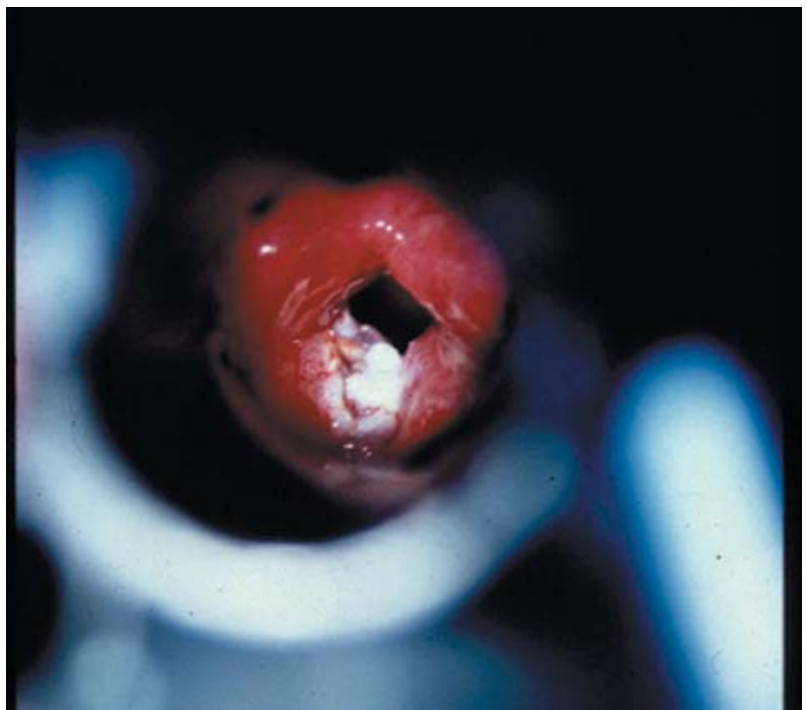

Figure 3 Epiglottitis with candida infection (picture courtesy of the Advanced Life Support Group).

\section{Respiratory problems}

Respiratory problems account for about $40 \%$ of children admitted to hospital and many of these children have asthma. Croup is usually viral and presents with a seal like bark with or without systemic illness or associated stridor. Sudden onset, short history, drooling because of pain, and a very toxic child support the diagnosis of the now rare epiglottitis, which should be considered to be immediately life threatening (fig 3).

Wheezing in babies may be attributable to a variety of causes, two of the commoner ones being asthma or

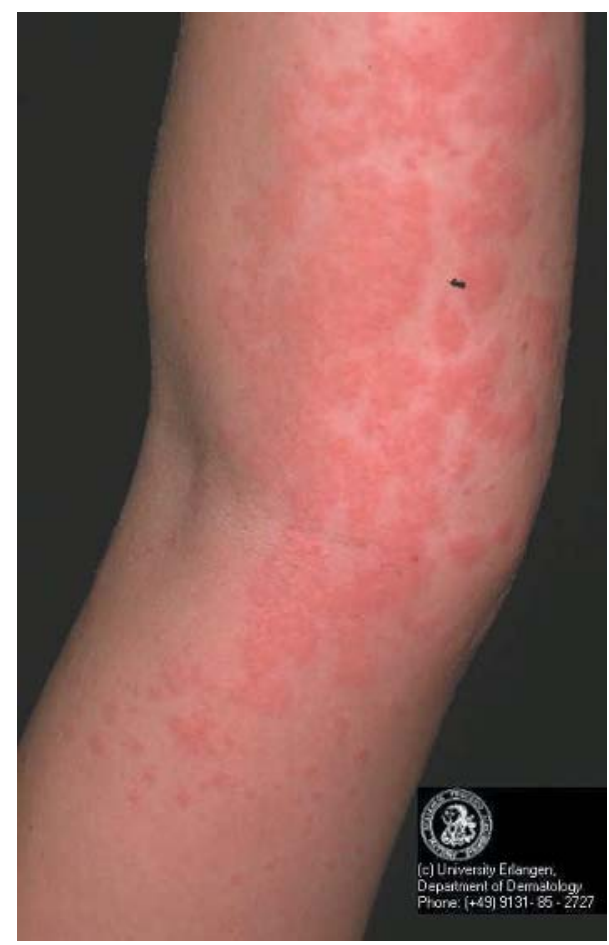

Figure 4 Urticarial rash, often seen in anaphylactic reactions (picture courtesy of the Advanced Life Support Group/University of Erlangen). bronchiolitis, the second resulting in the hospitalisation of $2 \%-3 \%$ of infants each year. Bronchiolitis is seasonal, occurring in the winter months and classically fine inspiratory crepitations may be heard on auscultaton. In older children asthma is a more likely cause, but anaphylaxis should be considered as an unlikely possibility in a child with a first presentation of wheezing (fig 4).

Significant respiratory tract infections, including pneumonia, also occur in children and can occasionally result in respiratory failure, septicaemia, hypoglycaemia, or dehydration because of the inability to feed.

\section{Illnesses rarely requiring hospital admission}

Table 1 describes common illnesses and presentations in children that rarely require hospital admission. Upper respiratory tract infections are particularly common in children, but foreign bodies in the airway should always be considered as a possible explanation of mild stridor or wheeze in otherwise well children. Children are also susceptible to a wide range of viral infections, many of which present with rashes of various descriptions.

Symptomatic treatment for pain or fever consists of paracetamol or ibuprofen. Both drugs can be used together for their synergistic effect "staggering" the doses if required. Encourage maintenance of an intake of (preferably) clear fluids.

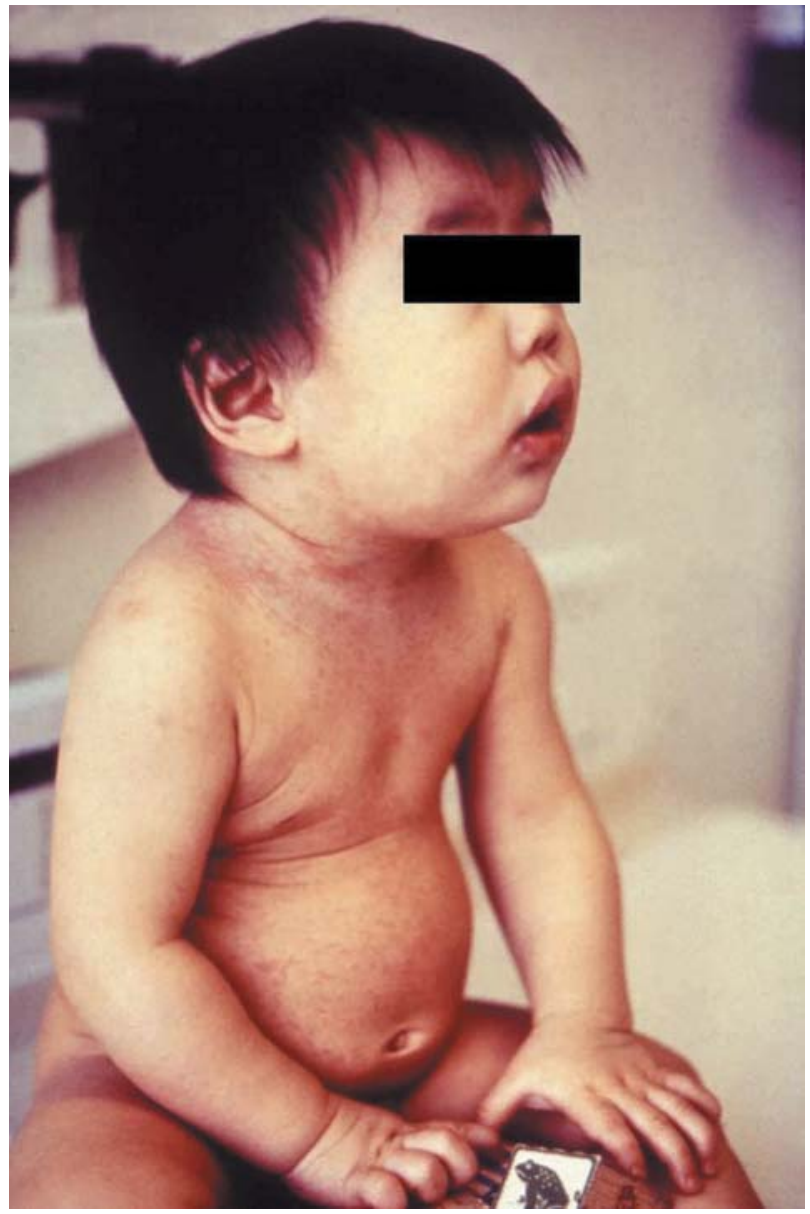

Figure 5 Rubella (picture courtesy of the Advanced Life Support Group). 
Table 1 Diagnosis, treatment, and disposition of common childhood illnesses not requiring hospital admission

\begin{tabular}{|c|c|c|c|c|}
\hline Common conditions & Subjective findings & $\begin{array}{l}\text { Objective findings (only some } \\
\text { may be present and only most } \\
\text { common are listed) }\end{array}$ & Plan & Disposition \\
\hline $\begin{array}{l}\text { General } \\
\text { Fever }\end{array}$ & $\begin{array}{l}\text { Hot and unwell } \\
\text { Miserable } \\
\text { - May be off food/fluids }\end{array}$ & $\begin{array}{l}\text { Depends on cause (must be } \\
\text { sought and found) }\end{array}$ & $\begin{array}{l}\text { Exclude serious cause } \\
\text { Symptomatic treatment } \\
\text { Cause must be sought } \\
\text { (including urine culture } \\
\text { if no other cause found) } \\
\text { Do not give antibiotics if cause } \\
\text { unknown }\end{array}$ & $\begin{array}{l}\text { Care at home, refer for } \\
\text { further investigations if } \\
\text { cause cannot be identified } \\
\text { and child significantly } \\
\text { unwell or serious cause } \\
\text { cannot be excluded }\end{array}$ \\
\hline Vomiting & $\begin{array}{l}\text { Frequency ? blood } \\
\text { ?tolerating clear fluids } \\
\text { ?bile stained }\end{array}$ & $\begin{array}{l}\text { Rule out: } \\
\text { dehydration } \\
\bigcirc \text { other sign of infection } \\
\text { Surgical pathology }\end{array}$ & $\begin{array}{l}\text { Exclude abdominal or } \\
\text { other serious pathology } \\
\text { If tolerating clear fluids, } \\
\text { encourage clear fluids till } \\
\text { improving then solid diet } \\
\text { Do not give antiemetics }\end{array}$ & $\begin{array}{l}\text { Care at home unless very } \\
\text { unwell/dehydrated or } \\
\text { significant pathology cannot } \\
\text { II be excluded }\end{array}$ \\
\hline Diarrhoea & $\begin{array}{l}\text { Need description } \\
\text { ?blood ?slime } \\
\text { ?watery ?amount? smell } \\
\text { May be vomiting or } \\
\text { anorexic }\end{array}$ & $\begin{array}{l}\text { Rule out: } \\
\text { abdominal abnormalities } \\
\text { signs of dehydration } \\
\text { other signs of infection }\end{array}$ & $\begin{array}{l}\text { Encourage clear/ } \\
\text { electrolyte replacement fluids } \\
\text { to re-hydrate only } \\
\text { Exclude occult infection and } \\
\text { dehydration } \\
\text { - Exclude other abdominal } \\
\text { pathology } \\
\text { Continue breastfeeding } \\
\text { throughout. Recommence } \\
\text { solids and formula feeds after } \\
\text { re-hydrating } \\
\text { Avoid foods high in fat or } \\
\text { simple sugars } \\
\text { Do not give antidiarrhoeal } \\
\text { agents }\end{array}$ & $\begin{array}{l}\text { Care at home unless very } \\
\text { unwell/dehydrated or } \\
\text { history of bloody diarrhoea, } \\
\text { or significant pathology } \\
\text { cannot be excluded }\end{array}$ \\
\hline $\begin{array}{l}\text { Respiratory } \\
\text { Upper respiratory tract } \\
\text { infection }\end{array}$ & $\begin{array}{l}\text { Cough } \\
\text { "Cold" } \\
\text { - Sore throat } \\
\text { Snuffly } \\
\text { - Hot and miserable } \\
\text { - May be off food }\end{array}$ & $\begin{array}{l}\text { Inflamed throat } \\
\text { Otitis media } \\
\text { Coryza, } \\
\text { Chest clear } \\
\text { Fever }\end{array}$ & $\begin{array}{l}\text { Symptomatic treatment } \\
\text { No antibiotics } \\
\text { Review if fluid intake poor }\end{array}$ & - Care at home \\
\hline Croup (mild) & $\begin{array}{l}\text { Barking cough } \\
\text { Noisy breathing } \\
\text { May be worse at night }\end{array}$ & $\begin{array}{l}\text { Barking cough } \\
\text { - May have mild stridor } \\
\text { Child not distressed } \\
\text { - Mild fever possible }\end{array}$ & $\begin{array}{l}\text { Nebulised budesonide or } \\
\text { oral dexamethasone }\end{array}$ & $\begin{array}{l}\text { Care at home unless } \\
\text { systemically unwell or } \\
\text { deteriorating }\end{array}$ \\
\hline Asthma (mild) & $\begin{array}{l}\text { Wheeze } \\
\text { Cough } \\
\text { May be URTI }\end{array}$ & $\begin{array}{l}\text { - Bilateral wheeze } \\
\text { Good air entry } \\
\text { May be tachypnoeic } \\
\text { Child not distressed }\end{array}$ & $\begin{array}{l}\text { Adjustment of dose of } \\
\text { bronchodilator } \\
\text { Check technique of } \\
\text { administration using spacer } \\
\text { Oral (soluble) prednisolone }\end{array}$ & $\begin{array}{l}\text { Care at home unless no } \\
\text { response to treatment, } \\
\text { deteriorating, or history of } \\
\text { previous ITU admission }\end{array}$ \\
\hline Bronchiolitis (mild) & $\begin{array}{l}\text { URT symptoms followed } \\
\text { by lower respiratory } \\
\text { symptoms }\end{array}$ & $\begin{array}{l}\text { Not distressed } \\
\text { Mild tachypnoea } \\
\text { Mild fever possible } \\
\text { Bilateral inspiratory fine } \\
\text { crackles and wheeze }\end{array}$ & - Symptomatic treatment & $\begin{array}{l}\text { Care at home; consider } \\
\text { need for follow up visit and } \\
\text { encourage recall if condition } \\
\text { deteriorates (especially } \\
\text { reluctance to feed or } \\
\text { breathing difficulty). Very } \\
\text { low threshold for admission } \\
\text { in babies under } 2 \text { months } \\
\text { old }\end{array}$ \\
\hline $\begin{array}{l}\text { ENT/eyes } \\
\text { Conjunctivitis }\end{array}$ & $\begin{array}{l}\text { Sore gritty eyes } \\
\text { Normal visual acuity }\end{array}$ & $\begin{array}{l}\text { Mildly inflamed conjunctiva, } \\
\text { often bilaterally } \\
\text { - Sometimes purulent discharge }\end{array}$ & $\begin{array}{l}\text { - Regular cleaning with } \\
\text { cooled boiled water } \\
\text { - Antibiotic eye drops }\end{array}$ & - Care at home \\
\hline Foreign body & $\begin{array}{l}\text { History of witnessed } \\
\text { insertion of object in } \\
\text { nose, ear } \\
\text { "Missing" object } \\
\text { Sudden respiratory } \\
\text { distress }\end{array}$ & $\begin{array}{l}\text { Foreign body visible } \\
\text { Stridor } \\
\text { Wheeze } \\
\text { Unequal air entry }\end{array}$ & $\begin{array}{l}\text { May be possible to } \\
\text { remove - if not refer to } \\
\text { appropriate specialist }\end{array}$ & $\begin{array}{l}\text { Care at home if object } \\
\text { removed, otherwise refer to } \\
\text { A\&E } \\
\text { Do not attempt to remove } \\
\text { blindly if lodged in pharynx }\end{array}$ \\
\hline
\end{tabular}


Table 1 Continued

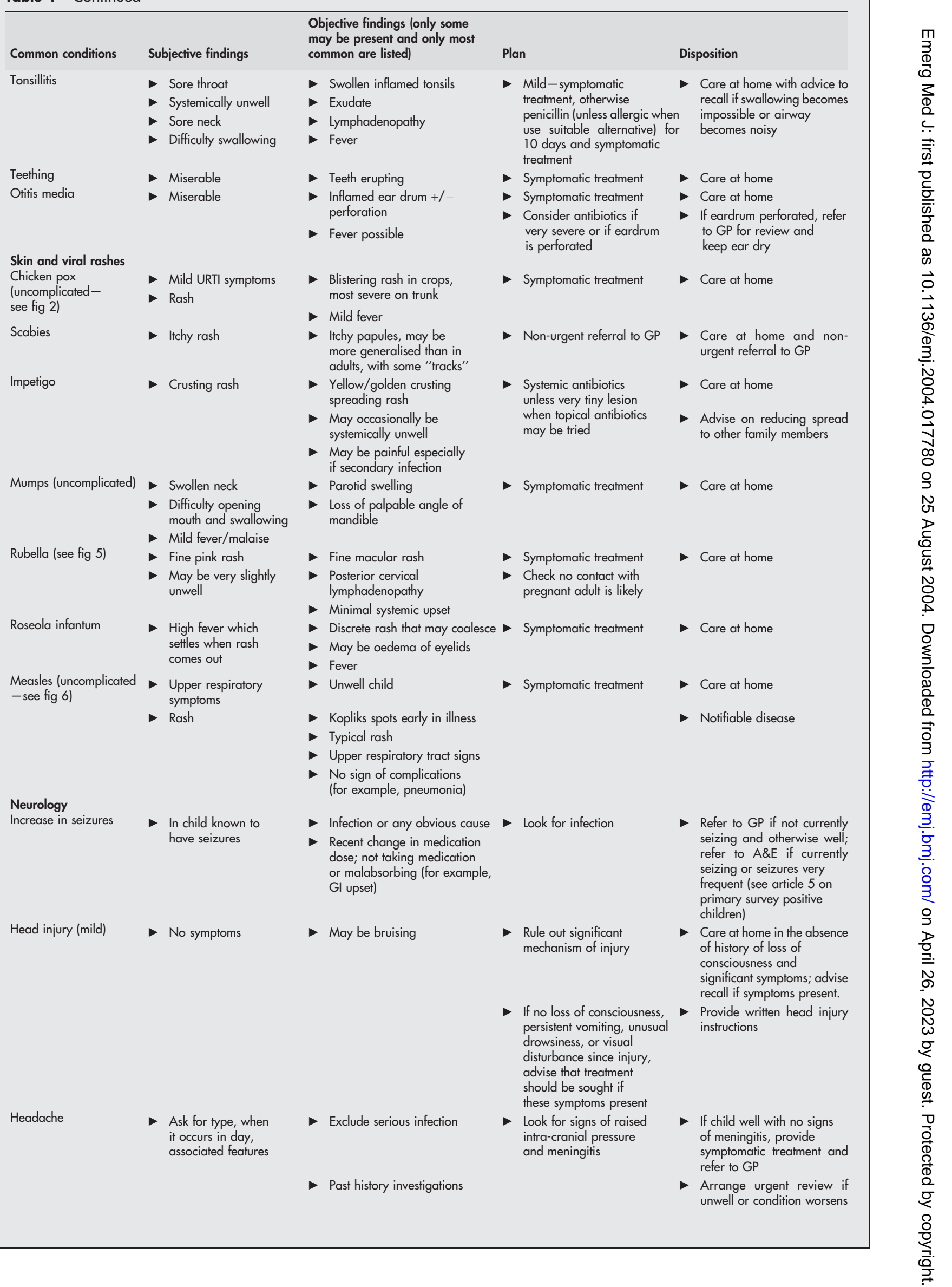




\begin{tabular}{|c|c|c|c|c|}
\hline Common conditions & Subjective findings & $\begin{array}{l}\text { Objective findings (only some } \\
\text { may be present and only most } \\
\text { common are listed) }\end{array}$ & Plan & Disposition \\
\hline Febrile convulsions & $\begin{array}{l}\text { Fever, child known to } \\
\text { have febrile convulsions }\end{array}$ & $\begin{array}{l}\text { Fever } \\
\text { Infection } \\
\text { Usual age range } \\
\text { approx. } 6 \text { months to } 6 \text { years }\end{array}$ & $\begin{array}{l}\text { Locate source of infection } \\
\text { and treat, referring to } \\
\text { hospital if serious cause } \\
\text { found or if no cause found } \\
\text { Check blood sugar }\end{array}$ & $\begin{array}{l}\text { Care at home for simple } \\
\text { febrile convulsions, } \\
\text { provided } \\
\text { This is not the first fit } \\
\text { It is a simple convulsion } \\
\text { The cause of the fever has } \\
\text { been identified and is benign } \\
\text { No more than one fit in a } \\
24 \text { hour period } \\
\text { The parents are confident } \\
\text { about caring for the child }\end{array}$ \\
\hline $\begin{array}{l}\text { Abdomen } \\
\text { Abdominal pain } \\
\text { (colicky) }\end{array}$ & - May be irritable & $\begin{array}{l}\text { Rule out surgical } \\
\text { problem abnormalities } \\
\text { Look for associated features } \\
\text { (see above) }\end{array}$ & $\begin{array}{l}\text { Exclude appendicitis, } \\
\text { obstruction. or other } \\
\text { pathology } \\
\text { Symptomatic treatment }\end{array}$ & $\begin{array}{l}\text { If child is completely well, } \\
\text { refer to GP. If child is unwell } \\
\text { or parents are concerned, } \\
\text { refer urgently to GP or } \\
\text { hospital }\end{array}$ \\
\hline Dysuria & $\begin{array}{l}\text { Complaining of pain } \\
\text { when passing urine }\end{array}$ & $\begin{array}{l}\text { Balanitis possible } \\
\text { Rule out renal tenderness } \\
\text { Check otherwise well or } \\
\text { minimum systemic upset }\end{array}$ & $\begin{array}{l}\text { Mild balanitis can be } \\
\text { treated with salt baths } \\
\text { If balanitis is severe } \\
\text { will require antibiotics } \\
\text { If no balanitis check } \\
\text { urine culture and treat } \\
\text { for urinary tract infection } \\
\text { till results of culture available }\end{array}$ & $\begin{array}{l}\text { Care at home; refer for } \\
\text { further investigations if no } \\
\text { cause found }\end{array}$ \\
\hline
\end{tabular}

\section{结 Pitfall}

lbuprofen is contraindicated in children with asthma

The choice of antibiotic and some other treatments may vary according to local protocols or where complications occur.

\section{To hospitalise or not}

In many situations it can be difficult to decide whether to send children to hospital because they fall neither into the category of "primary survey positive patients" nor that of the relatively well child described in table 2 . The signs of serious illness in children are subtle and it is usually wise to err on the safe side and ask for a second opinion from hospital specialists. However, some pointers that may be helpful in encouraging hospital referral and have been evidence based are given below. ${ }^{1}$

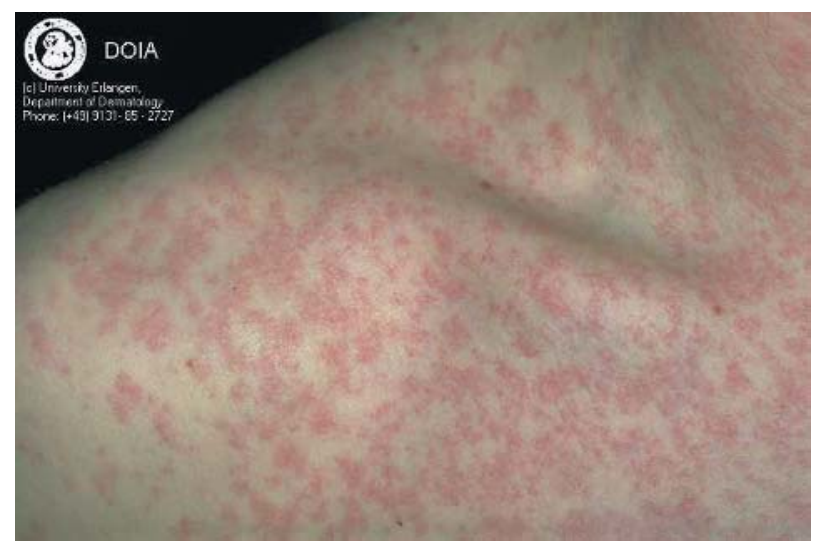

Figure 6 Measles (picture courtesy of the Advanced Life Support Group/University of Erlangen).
General

- Babies less than 2 months old

- Comorbidity with a chronic disorder-for example, congenital heart disease

- Lack of social support-parents unable to cope, previous child abuse

Upper airway obstruction

- Signs of severe respiratory distress

- Signs of serious illness

- Strong suspicion of aspiration

- Stertorous (snoring) breathing

Wheezing and coughing

- Suspicion of foreign body

- Child under 2 months old

- Significant respiratory distress

- History of apnoeic attack

Febrile seizures

- First febrile convulsion

- Infants less than 18 months old with fever or history of treatment with antibiotics

- Complex seizures

- Drowsiness before seizure

- Contact with GP in previous 24 hours

- Tense fontanelles or possible neck stiffness

- Vomiting before seizure

- No focus of infection

- Parental anxiety

Afebrile seizures

- Depressed conscious level more than one hour after fit

- New neurological signs

- Age less than 1 year

- Signs of raised intracranial pressure

- Complex seizure

- Signs of meningism

- Unwell

- Signs of aspiration

- Parental anxiety 
Table 2 Management of common problems in technologically assisted children

\begin{tabular}{|c|c|c|}
\hline Device & Problem(s) & Solution(s) \\
\hline Tracheostomy tube & Obstruction & $\begin{array}{l}1 \text { Confirm tube is correctly positioned } \\
2 \text { Remove the speech cap from fenestrated tubes } \\
3 \text { Suction the tube to remove secretions (use the tube's obturator if } \\
\text { suction is not available) } \\
4 \text { Remove the tracheostomy tube and replace } \\
5 \text { Ventilate to confirm correct position and patency }\end{array}$ \\
\hline Home ventilator (fig 8) & Failure & $\begin{array}{l}\text { 1 Confirm the problem is not attributable to airway obstruction } \\
2 \text {. Assist breathing with a self inflating bag with supplementary } \\
\text { oxygen and transport to hospital }\end{array}$ \\
\hline \multirow[t]{4}{*}{ Central venous catheter } & 2 Broken/perforated catheter & $\begin{array}{l}1 \text { Dress the wound } \\
2 \text { Apply direct pressure to control bleeding } \\
3 \text { Contact hospital and inform the child's medical team } \\
1 \text { Clamp catheter tube proximal to break to prevent air embolus } \\
2 \text { Transfer to hospital }\end{array}$ \\
\hline & 3 Infection at insertion site/septicaemia & $\begin{array}{l}\text { 1 Discontinue use } \\
2 \text { If the child is very ill, transfer treating A, B, C as for primary survey } \\
\text { positive patients. Do not remove the catheter! } \\
\text { 3.Mild local infection will also need hospital review }\end{array}$ \\
\hline & 4 Obstruction & $\begin{array}{l}1 \text { Contact hospital and arrange review and discuss need for } \\
\text { rehydration/prevention of hypoglycaemia (will depend on the } \\
\text { purpose of the tube) }\end{array}$ \\
\hline & $\begin{array}{l}5 \text { Air embolism (after incorrect } \\
\text { flushing technique) }\end{array}$ & $\begin{array}{l}\text { 1 Clamp the tube } \\
\text { 2. Transfer urgently to hospital in a head down, left lateral position } \\
3 \text { Give high concentration oxygen } \\
4 \text { Provide CPR if necessary }\end{array}$ \\
\hline \multirow[t]{2}{*}{ Ventriculoperitoneal (VP) shunts } & $\begin{array}{l}1 \text { Obstruction (causing raised } \\
\text { intracranial pressure) }\end{array}$ & $\begin{array}{l}1 \text { If child seriously ill treat } A B C \text { s and transfer immediately to hospital. } \\
2 \text { Use controlled hyperventilation (at a rate of five inflations per } \\
\text { minute above the child's normal respiratory rate) if Cushing's triad } \\
\text { present. Otherwise transfer urgently. }\end{array}$ \\
\hline & 2 Infection/septicaemia & $\begin{array}{l}1 \text { Transfer urgently to hospital. Manage as meningitis. } \\
2 \text { Consider need for antibiotics and supportive therapy }\end{array}$ \\
\hline \multirow[t]{2}{*}{$\begin{array}{l}\text { Nasogastric or percutaneous } \\
\text { feeding tubes (PEGs) }\end{array}$} & 1 Dislodged & $\begin{array}{l}1 \text { Discontinue use. } \\
2 \text { Remove nasogastric tube if not already out } \\
3 \text { Either replace or arrange transfer to healthcare personnel who } \\
\text { usually replace tube. (Many parents and some children will replace } \\
\text { nasogastric tubes themselves). } \\
4 \text { If a PEG is dislodged, arrange transfer to hospital for review by the } \\
\text { child's medical team }\end{array}$ \\
\hline & 2 Infected site & 1 Clean and dress the site. Arrange hospital review. \\
\hline
\end{tabular}

Diarrhoea and vomiting

- Doubt in diagnosis of gastroenteritis

- Age less than 6 months

- More than four vomits per day

- More than eight liquid stools per day

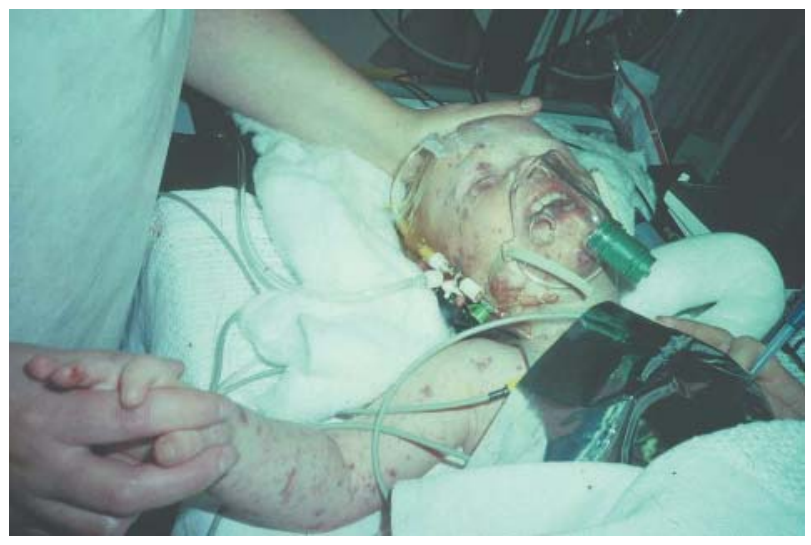

Figure 7 Child with meningococcal septicaemia: note petechial rash (picture courtesy of Fiona Mair).

\section{Findings for exclusion if hospital attendance is not considered appropriate}

Viral infections that commonly result in childhood illnesses may occasionally be associated with serious complications. Mumps, measles, chicken pox, and rubella can all result in

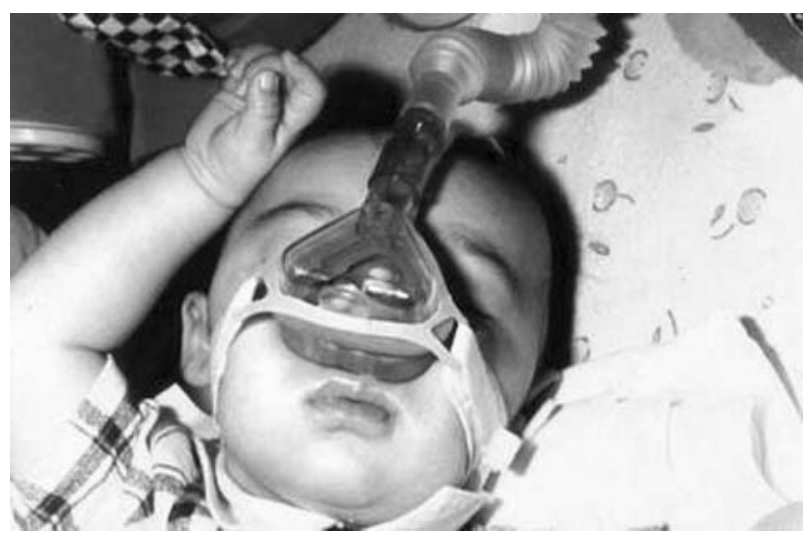

Figure 8 Child on home non-invasive ventilation (picture courtesy of the Advanced Life Support Group). 


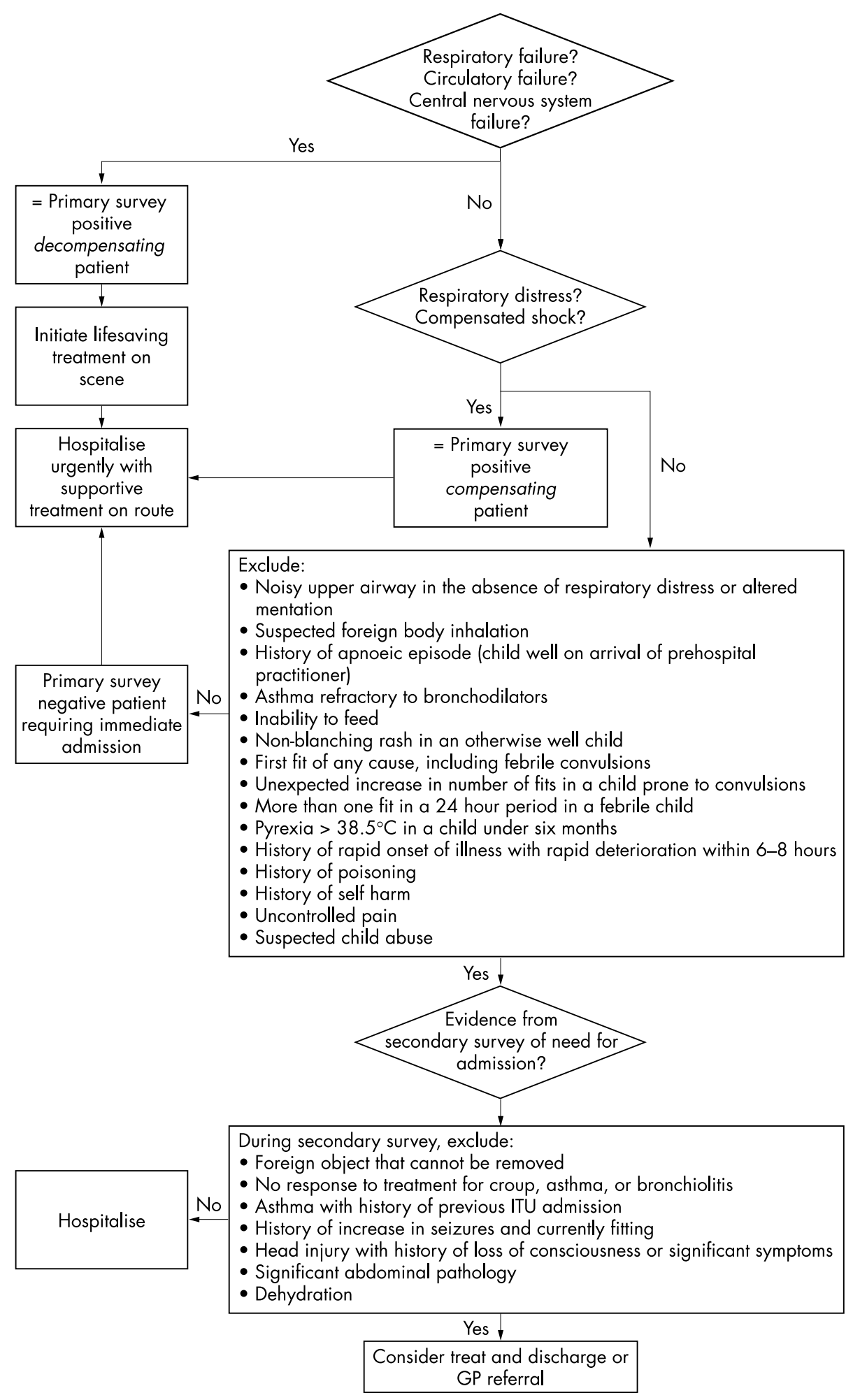

Figure 9 Disposition flow chart.

inflammation and damage of a number of organs. Complications can include meningitis, encephalitis, hepatitis, and pancreatitis. Children presenting with these conditions will require urgent referral for supportive treatment.

Always consider meningitis in children with flu-like illness who have deteriorated rapidly over four to six hours (fig 7).

Children with evidence of dehydration or reduced urine output, or both, regardless of cause, may require intravenous fluids including dextrose. Abdominal pain will require referral if significant pathology cannot be ruled out.

\section{DISPOSITION FLOW CHART}

Figure 9 diagrams the decision making process for determining the urgency of care required and the appropriate disposition for children with a range of presenting problems. 
Table 3 Drugs commonly used in childhood illnesses

\begin{tabular}{|c|c|c|c|}
\hline Drug name & Indications & Contraindications & Dose \\
\hline $\begin{array}{l}\text { Adrenaline } \\
\text { (epinephrine) }\end{array}$ & $\begin{array}{l}\text { Anaphylaxis associated with wheeze } \\
\text { or respiratory distress (including } \\
\text { cyanosis) unrelieved by salbutamol } \\
\text { OR stridor OR clinical signs of shock } \\
\text { (systolic BP }<90 \mathrm{~mm} \mathrm{Hg} \text { ) }\end{array}$ & None & $\begin{array}{l}\text { 6-11 years: } 250 \mu \mathrm{g}(0.25 \mathrm{ml} \text { of } 1: 1000) \mathrm{IM} \text {. } \\
6 \text { months-5 years: } 120 \mu \mathrm{g}(0.12 \mathrm{ml} \text { of } \\
1: 1000) \mathrm{IM} \text {. } \\
<6 \text { months: } 50 \mu \mathrm{g}(0.05 \mathrm{ml} \text { of } 1: 1000) \mathrm{IM} \text {. } \\
\text { All ages: repeat after five minutes if necessary. }\end{array}$ \\
\hline $\begin{array}{l}\text { Adrenaline } \\
\text { (epinephrine) }\end{array}$ & $\begin{array}{l}\text { Croup associated with } \\
\text { severe respiratory distress }\end{array}$ & None & $\begin{array}{l}5 \mathrm{ml} 1: 1000 \text { via nebuliser once only while } \\
\text { definitive care arranged }\end{array}$ \\
\hline Benzylpenicillin & $\begin{array}{l}\text { Meningococcal septicaemia } \\
\text { (also see cefotaxime) }\end{array}$ & $\begin{array}{l}\text { Confirmed penicillin } \\
\text { allergy }\end{array}$ & $\begin{array}{l}\text { For IV/IO use, dilute } 600 \mathrm{mg} \text { in } 10 \mathrm{ml} \text {. For IM, } \\
\text { dilute } 600 \mathrm{mg} \text { in } 2 \mathrm{ml} . \\
\text { Less than } 1 \text { year } 300 \mathrm{mg}(5 \mathrm{ml} \mathrm{IV} / 10 \text { or } \\
1 \mathrm{ml} \mathrm{IM}) \\
1-9 \text { years } 600 \mathrm{mg}(10 \mathrm{ml} \mathrm{IV} / 10 \text { or } 2 \mathrm{ml} \mathrm{IM)} \\
>9 \text { years and adult } 1.2 \mathrm{~g}(20 \mathrm{ml} \mathrm{IV} / 10 \text { or } \\
4 \mathrm{ml} \mathrm{IM})\end{array}$ \\
\hline Budesonide & Croup & Less than 3 months old & $2 \mathrm{mg}$ via nebuliser, once only \\
\hline Cefotaxime & Meningococcal septicaemia & Allergy & $80 \mathrm{mg} / \mathrm{kg}$ \\
\hline $\begin{array}{l}\text { Dexamethasone } \\
\text { syrup }\end{array}$ & Croup & None & $0.15 \mathrm{mg} / \mathrm{kg} 10$ \\
\hline Dextrose $10 \%$ & Hypoglycaemia & None & $5 \mathrm{ml} / \mathrm{kg} \mathrm{IV} / \mathrm{IO}$, titrated to blood sugar \\
\hline Diazepam & Continuous or recurrent fits & None & $\begin{array}{l}\text { Rectal: } 0 \text { to } 1 \text { years } 2.5 \mathrm{mg} ; 1 \text { to } 3 \text { years } 5 \mathrm{mg} \text {; } \\
4 \text { to } 12 \text { years } 10 \mathrm{mg} \text {. } \\
\text { IV: } 250 \text { to } 400 \mu \mathrm{g} / \mathrm{kg} \\
\text { All ages: repeat if required after } 5 \text { minutes. }\end{array}$ \\
\hline $\begin{array}{l}\text { Hydrocortisone } \\
\text { lbuprofen }\end{array}$ & $\begin{array}{l}\text { Anaphylaxis; asthma } \\
\text { Fever and mild to moderate pain }\end{array}$ & $\begin{array}{l}\text { None } \\
\text { Known sensitivity } \\
\text { Asthma }\end{array}$ & $\begin{array}{l}4 \mathrm{mg} / \mathrm{kg} \mathrm{IV} \\
10 \mathrm{mg} / \mathrm{kg} \text { up to thrice daily }\end{array}$ \\
\hline Ipratropium bromide & Asthma/bronchiolitis & None & $\begin{array}{l}\text { Up to } 7 \text { years, } 125 \mu \mathrm{g} \\
>7 \text { years } 250 \mu \mathrm{g} \text { via nebuliser }\end{array}$ \\
\hline Morphine & Moderate to severe pain & $\begin{array}{l}\text { Known sensitivity to opioids } \\
\text { Respiratory depression, } \\
\text { hypotension, or reduced GCS }(<12)\end{array}$ & $\begin{array}{l}0.1 \mathrm{mg} / \mathrm{kg} \text {, repeated at } 5 \mathrm{~min} \text { intervals to a } \\
\text { maximum dose of } 0.2 \mathrm{mg} / \mathrm{kg} \text {. Use half dose in } \\
\text { children less than } 1 \text { year old }\end{array}$ \\
\hline Naloxone & Reversal of opioid overdose & None & $\begin{array}{l}10 \mu \mathrm{g} / \mathrm{kg} \text { followed by } 100 \mu \mathrm{g} / \mathrm{kg} \text { titrated to } \\
\text { effect }\end{array}$ \\
\hline $\begin{array}{l}\text { Paracetamol suspension } \\
\text { or soluble tablets }\end{array}$ & Fever and mild to moderate pain & Under 2 months & $\begin{array}{l}15 \mathrm{mg} / \mathrm{kg} \text { (maximum single dose } 1 \mathrm{~g} \text { ) } \\
\text { PO } 4-6 \text { hourly }\end{array}$ \\
\hline $\begin{array}{l}\text { Prednisolone } \\
\text { soluble tablets }\end{array}$ & Exacerbations of asthma & None & $\begin{array}{l}1 \mathrm{mg} / \mathrm{kg} \text { (maximum single dose } 60 \mathrm{mg} \text { ) PO, } \\
\text { twice daily for } 5 \text { days }\end{array}$ \\
\hline Salbutamol & Asthma/bronchiolitis & None & $\begin{array}{l}<1 \text { year } 2.5 \mathrm{mg} \text { (if ineffective do not repeat). } \\
1 \text { to } 5 \text { years } 2.5 \mathrm{mg} \text { repeated at } 15 \mathrm{~min} \\
\text { intervals, titrated to effect } \\
>5 \text { years } 5 \mathrm{mg} \text { repeated at } 15 \mathrm{~min} \text { intervals, } \\
\text { titrated to effect }\end{array}$ \\
\hline Fucidic acid eye drops & $\begin{array}{l}\text { Eye infection-for prophylaxis or } \\
\text { treatment }\end{array}$ & Allergy & Twice daily \\
\hline
\end{tabular}

Known allergy to any of the drugs or constituents is a contraindication in all cases.

\section{瑜 Tip}

If in doubt, ask for help! (Which may well include seeking a hospital opinion)

\section{琴 Pitfall}

Lack of a non-blanching rash does not rule out meningococcal septicaemia

\section{TECHNOLOGICALLY ASSISTED CHILDREN}

Children requiring technological support such as assisted ventilation and tube feeding are increasingly being cared for at home. Prehospital practitioners called to assist such children may be unfamiliar with this equipment but should be aware of the small number of interventions that can be appropriately made in the out of hospital setting. Remember that both parents, carers, and the child may be able to offer expert advice themselves, and should also be able to provide contact details for professional advice. Table 2 describes a number of problems and relevant interventions. Further information may be found on the journal web site (http:// www.emjonline.com/supplemental) 


\section{领 Tip}

Always be sure you are satisfied that any ill child does not have meningitis, appendicitis, or urinary tract infection. If you are not certain, refer for investigation

\section{金 Pitfall}

If a child is on continuous enteral feeds, remember to monitor for hypoglycaemia if it is necessary to discontinue an infusion

\section{COMMUNICATION AND FOLLOW UP}

Parents do not ask for help unless they are worried. Provide a simple explanation of your findings and of the implications of these for their child's health. Offer reassurance and clear parameters for re-contacting the service if things are not going according to plan. Where appropriate provide written advice. Always seek help from someone more expert or the hospital if unsure.

\section{PHARMACOPOEIA}

Table 3 describes the indications, contraindications, and doses of drugs commonly used to treat illness in childhood.

\section{Further reading}

Advanced Life Support Group, eds. Advanced paediatric life support. The practical approach. 3rd ed. Manchester: Advanced Life Support Group, 1997.

Advanced Life Support Group, eds. Pre-hospital paediatric life support. Manchester: Advanced Life Support Group, 1999.

American Academy of Pediatrics. Pediatric education for prehospital professionals. Sudbury MA: Jones and Bartlett, 2000.
Behrman RE, Kliegman R. Essentials of paediatrics. Philadephia: WB Saunders, 1990.

Morley CJ, Thornton AJ, Cole TJ, et al. Baby check. http:// nicutools.orcon.net.nz/MediCalcs/BabyCheck.html>

(accessed 29 Feb 2004).

Ninnis N, Glennie L. Lessons from research for doctors in training. Bristol: Meningitis Research Foundation, 2004.

\section{ACKNOWLEDGEMENTS}

Suggestions made by Peter Driscoll and Jim Wardrope resulted in improvements to an earlier draft of this article. Our thanks to them and to Fiona Mair, who generously provided her time and expertise to source the pictures.

\section{AUTHOR CONTRIBUTIONS}

Malcolm Woollard wrote the first draft of the paper. Malcolm Woollard and Fiona Jewkes edited all subsequent drafts.

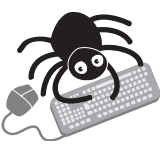

Further information on technologically assisted children is available on line (http://www.emjonline. com/supplemental).

\section{Authors' affiliations}

F Jewkes, Wiltshire Ambulance Service NHS Trust, UK

M Woollard, Pre-hospital Care Research Unit, Department of Academic Emergency Medicine, The James Cook University Hospital/University of Teesside, UK

\section{REFERENCE}

1 Paediatric Accident and Emergency Research Group. Evidence based guidelines for acute management with breathing difficulty, diarrhoea +/vomiting, post-seizure. Cheltenham: Children Nationwide, 2002. 